\title{
Volatiles in melt inclusions and apatite from Erebus phonolite
}

\author{
Weiran Li ${ }^{n}$, Fidel Costa ${ }^{1.2}$, CLIVE OPPENHEIMER ${ }^{3}$
}

Earth Observatory of Singapore, Nanyang Technological University (*correspondence: weiran.li@ntu.edu.sg)

2 Asian School of Environment, Nanyang Technological

University

${ }^{3}$ Department of Geography, University of Cambridge

Magmatic volatiles such as $\mathrm{CO}_{2}$ and $\mathrm{H}_{2} \mathrm{O}$ play a major role in magmatic processes and eruptive behaviour. Abundances of $\mathrm{H}_{2} \mathrm{O}$ in the melt can be determined by volatile measurements on apatite, combined with thermodynamic analyses of $\mathrm{F}-\mathrm{Cl}-\mathrm{OH}$ partitioning between apatite and melt [1]. A similar method should be possible to assess melt $\mathrm{CO}_{2}$ contents but studies of the concentration of $\mathrm{CO}_{2}$ in apatite and its partition behaviour are few. Here we provide new measurements (using SIMS) and thermodynamic analysis of $\mathrm{CO}_{2}, \mathrm{H}_{2} \mathrm{O}, \mathrm{F}, \mathrm{Cl}$ and $\mathrm{S}$ concentrations in co-existing apatite and phonolitic glass inclusions, hosted by anorthoclase megacrystals of lava bomb samples from Mt. Erebus (Antarctica; [2]). We find that the melt inclusions (MIs) contain similar volatile compositions: $\sim 0.16$ wt. $\% \mathrm{H}_{2} \mathrm{O}, \sim 90$ ppm $\mathrm{CO}_{2}, \sim 2100 \mathrm{ppm} \mathrm{F}, \sim 1400 \mathrm{ppm} \mathrm{Cl}, \sim 350 \mathrm{ppm} \mathrm{S}$. The coexisting fluorapatite crystals have a limited range of $\mathrm{F} \approx$ 3.5 wt. $\%, \mathrm{Cl} \approx 0.13$ wt. $\%, \mathrm{H}_{2} \mathrm{O} \approx 0.06$ wt. $\%$, and $\mathrm{S} \leq 5 \mathrm{ppm}$, but a wide variation in $\mathrm{CO}_{2}$ from $\approx 120$ to $1600 \mathrm{ppm}$. Apatite-melt inclusion pairs indicate exchange coefficient $\left(\mathrm{K}_{\mathrm{b}}\right)$ for $\mathrm{Cl}-\mathrm{F}$ of $\sim 0.11$, equivalent to that calculated from [1] at $950-1000{ }^{\circ} \mathrm{C}$. Using the apatite hygrometer model of [1], the melt should contain $>0.5 \mathrm{wt} . \% \mathrm{H}_{2} \mathrm{O}$. This is higher than that measured in MIs but can be explained by diffusive $\mathrm{H}_{2} \mathrm{O}$ loss. The calculated values of the Nernst partition coefficient (D) for $\mathrm{CO}_{2}$ are $\sim 1.6-2.8$, which are much higher than those (of $\sim 0.11-0.12$ ) determined by [3] at $1 \mathrm{GPa}$ and $1250{ }^{\circ} \mathrm{C}$ for trachytic melts and F-rich apatite. The calculated value of exchange coefficient $\mathrm{K}_{\mathrm{D}}$ for $\mathrm{H}_{2} \mathrm{O}-\mathrm{CO}_{2}$ (on the basis of wt.\%) is $\sim 0.04( \pm 0.02), \sim 10$ times lower than that determined at $1250{ }^{\circ} \mathrm{C}$ by [3]. This discrepancy can be explained by a temperature difference of $\sim 300{ }^{\circ} \mathrm{C}$, and is comparable to the difference in $\mathrm{K}_{\mathrm{b}}$ for $\mathrm{OH}-\mathrm{F}$ between 950 and $1250{ }^{\circ} \mathrm{C}$ [1]. More experimental studies on apatite-melt $\mathrm{CO}_{2}$ partitioning are needed to improve estimates of melt $\mathrm{CO}_{2}$ budgets from $\mathrm{CO}_{2}$ in apatite.

[1] Li \& Costa (2020) GCA 269, 203-222. [2] Moussallam et al. (2015) EPSL 413, 1-12. [3] Riker et al. (2018) Am Mineral 103, 260-270. 